\title{
Need for improving COVID-19 mortality registries: the case of Peru
}

\author{
Akram Hernández-Vásquez ${ }^{1 *}$ (D) Rodrigo Vargas-Fernández ${ }^{2} \mathbb{D}$, Jesús Eduardo Gamboa-Unsihuay ${ }^{3}$ (D) and \\ Diego Azañedo ${ }^{4}$ (D)
}

To the Editor:

The SARS-CoV-2 pandemic has generated unprecedented health consequences with a record of nearly 117 million cases and more than two million deaths in 188 countries as of July 2020 [1]. Peru was the 19th country in the world and fifth in Latin America [1] with the highest number of identified cases (1.5 million). In addition, there are 50 thousand deaths [2], and an excess of 355 deaths per 100,000 inhabitants by 2020 attributed to this condition compared to previous years [3]. Correct recording and monitoring of the dynamics of COVID-19 mortality are important to know the impact of the pandemic and the effectiveness of health measures, as well as to allow timely rethinking of these measures if necessary. However, under-registration of mortality has been identified in most Latin American countries, including Peru [4].

In Peru, the main sources of information on COVID-19 mortality are the National Informatics Deaths System (SINADEF in Spanish) and the Situational Room of the Ministry of Health of Peru (MINSA in Spanish). SINADEF is a virtual information system, in which medical personnel record the causes (basic, intermediate, direct, or intervening) of the death of patients, including those with suspected or confirmed COVID-19 cases [5]. In turn, the Situational Room of MINSA takes the National Center for Epidemiology, Prevention and Disease Control (CDC) as a source of information, which centralizes reports of all cases of death by COVID-19 verified by a laboratory test, recorded by health services at the national level through its systems of epidemiological surveillance and health intelligence [6].

\footnotetext{
* Correspondence: ahernandez@usil.edu.pe

${ }^{1}$ Universidad San Ignacio de Loyola, Vicerrectorado de Investigación, Centro de Excelencia en Investigaciones Económicas y Sociales en Salud, Lima, Peru Full list of author information is available at the end of the article
}

According to the World Health Organization (WHO), for epidemiological surveillance purposes, death by COVID-19 is considered to occur as a result of a clinical picture compatible with COVID-19, whether a suspected or confirmed case [7]. Likewise, the Pan American Health Organization (PAHO) points out that the codes U07.1 (identified virus) and U07.2 (unidentified virus) of the International Classification of Diseases 10th edition (ICD-10) should be used to record the cases of deaths due to this disease [8]. Despite these recommendations, in July 2020, the Situation Room of MINSA reported the presence of an under-registration of more than 3000 deaths in the period from March to July 2020 compared to the SINADEF records [9]. This reflects a major problem that does not allow assessment of the actual impact of the pandemic according to the recommendations of the WHO and PAHO, generating confusion among the population and decision-makers.

To determine the extent of this under-registration throughout the national territory and to know where this problem is concentrated, an ecological study was carried out to estimate mortality by COVID-19 at the departmental level from codes U07.1 and U07.2 recorded in SINA DEF (https://bit.ly/3hjRbOA) from the first reported case of COVID-19 in Peru to March 6, 2021, and compare the results with the figures reported by the Situational Room of MINSA in the same period (https://covid19. minsa.gob.pe/sala_situacional.asp). Furthermore, the code enabling the replicability of results in the $\mathrm{R}$ statistical program is available on the GitHub collaborative development platform (https://github.com/jeguns/ ComparacionMortalidad).

A total of 94,574 COVID-19 deaths recorded under the ICD-10 codes were identified: U07.1 $(\mathrm{n}=70,099)$ and U07.2 ( $\mathrm{n}=24,475)$ in SINADEF, while the Situational Room recorded 47,491 deaths by the same pathology (a difference of 47,088 deaths). This inconsistency 
Table 1 Comparison of the reported deaths from COVID-19 between the National Informatics Deaths System (SINADEF) and the Ministry of Health (MINSA) records (during the period from the first reported case of COVID-19 in Peru to March 6, 2021)

\begin{tabular}{|c|c|c|c|c|}
\hline \multirow[b]{2}{*}{ Departments } & \multicolumn{3}{|l|}{ SINADEF } & \multirow{2}{*}{$\begin{array}{l}\text { MINSA } \\
\text { Total COVID-19 deaths }\end{array}$} \\
\hline & Confirmed COVID-19 deaths & Suspected COVID-19 deaths & Total COVID-19 deaths & \\
\hline Lima & 32,273 & 12,671 & 44,944 & 20,770 \\
\hline Piura & 3959 & 1725 & 5684 & 2429 \\
\hline Callao & 3699 & 1378 & 5077 & 2515 \\
\hline Ica & 3444 & 983 & 4427 & 2297 \\
\hline Arequipa & 3025 & 1319 & 4344 & 2039 \\
\hline La Libertad & 2649 & 841 & 3490 & 2879 \\
\hline Junin & 2798 & 607 & 3405 & 1560 \\
\hline Lambayeque & 2280 & 711 & 2991 & 2164 \\
\hline Ancash & 2198 & 616 & 2814 & 1891 \\
\hline Cusco & 1737 & 332 & 2069 & 767 \\
\hline Loreto & 1005 & 846 & 1851 & 1212 \\
\hline Puno & 1479 & 315 & 1794 & 638 \\
\hline Cajamarca & 1571 & 215 & 1786 & 809 \\
\hline Huanuco & 1254 & 248 & 1502 & 766 \\
\hline San Martin & 1043 & 274 & 1317 & 899 \\
\hline Tacna & 931 & 160 & 1091 & 611 \\
\hline Ucayali & 677 & 331 & 1008 & 541 \\
\hline Ayacucho & 759 & 127 & 886 & 516 \\
\hline Moquegua & 579 & 256 & 835 & 461 \\
\hline Huancavelica & 565 & 113 & 678 & 243 \\
\hline Tumbes & 530 & 105 & 635 & 449 \\
\hline Apurimac & 451 & 112 & 563 & 277 \\
\hline Pasco & 407 & 70 & 477 & 249 \\
\hline Amazonas & 360 & 75 & 435 & 329 \\
\hline Madre de Dios & 400 & 29 & 429 & 180 \\
\hline Sin Registro & 26 & 16 & 42 & NA \\
\hline Total & 70,099 & 24,475 & 94,574 & 47,491 \\
\hline
\end{tabular}

Data updated until March 06, 2021

MINSA Ministry of Health of Peru, SINADEF National Informatics Deaths System

in the number of deaths by COVID-19 recorded by SINADEF (using encoding U07.1 and U07.2) and the Situational Room of MINSA is also found in most departments that make up Peru. Lima is the department with the highest number of deaths reported by COVID19 by both entities; thus, while MINSA reported a total of 20,770 deaths, SINADEF recorded 44,944, resulting in a difference of 24,184 deaths. Moreover, in the departments of Piura, the constitutional province of Callao, Ica, and Arequipa, there was a difference of more than two thounsands deaths when comparing the figures reported by MINSA and those estimated using the codes for COVID-19 of SINADEF. In addition, most departments of the mountains range have double or up to three times as many deaths according to SINADEF compared to MINSA. It should be noted that there are also
42 "no registration" department deaths in SINADEF (see Table 1).

These results show large differences between the figures reported by MINSA and SINADEF in all departments of Peru taking into account COVID-19 coding. These differences could be linked to the non-recording of deaths of suspected COVID-19 cases in a scenario of scarcity of diagnostic methods and operational capacity affecting various Latin American countries.

\section{Abbreviations}

SINADEF: National Informatics Deaths System; MINSA: Ministry of Health of Peru; WHO: World Health Organization; PAHO: Pan American Health

Organization; COVID-19: coronavirus disease

Acknowledgements

Not applicable. 


\section{Authors' contributions}

AHV conceived the study. JG analyzed and interpreted the mortality data. AHV, JG, RVF, and DA have written, reviewed the submitted manuscript, and approved the final manuscript for submission.

\section{Funding}

Self-funded

\section{Availability of data and materials}

The datasets analyzed during the current study are available in the SINADEF repository, https://bit.ly/3hjRbOA

\section{Declarations}

Ethics approval and consent to participate

Not applicable

\section{Consent for publication}

Not applicable

\section{Competing interests}

The authors declare that they have no competing interests.

\section{Author details}

'Universidad San Ignacio de Loyola, Vicerrectorado de Investigación, Centro de Excelencia en Investigaciones Económicas y Sociales en Salud, Lima, Peru. ${ }^{2}$ Universidad Científica del Sur, Lima, Peru. ${ }^{3}$ Universidad Nacional Agraria La Molina, Lima, Peru. ${ }^{4}$ Independent Researcher, Lima, Peru.

Received: 26 April 2021 Accepted: 26 May 2021

Published online: 16 June 2021

\section{References}

1. Johns Hopkins. COVID-19 Dashboard by the Center for Systems Science and Engineering (CSSE) at Johns Hopkins University [Internet]. JHU; 2020 [cited 2020 Jul 28]. Available from: https://coronavirus.jhu.edu/map.html

2. Covid 19 en el Perú - Ministerio del Salud. [cited 2020 Jul 28]. Available from: https://www.covid19.minsa.gob.pe/sala_situacional.asp

3. The Economist. Tracking covid-19 excess deaths across countries [Internet] 2020 [cited 2021 Mar 23]. Available from: https://www.economist.com/gra phic-detail/coronavirus-excess-deaths-tracker

4. Programa de las Naciones Unidas para el Desarrollo. Una tragedia peor de lo que creemos: las tasas de exceso de mortalidad sugieren que el número de muertes por COVID-19 se subestima enormemente en ALC UNDP; 2020 [cited 2021 March 6]. Available from: https:/www.latinamerica.undp.org/ content/rblac/es/home/presscenter/director-s-graph-for-thought/a-greatertragedy-than-we-know\%2D\%2Dexcess-mortality-rates-suggest-t.html

5. Vargas-Herrera J, Pardo Ruiz K, Garro Nuñez G, Miki Ohno J, Pérez-Lu JE, Valdez Huarcaya W, et al. Resultados preliminares del fortalecimiento del sistema informático nacional de defunciones. Rev Peru Med Exp Salud Publica. 2018;35(3):505-14. https://doi.org/10.17843/rpmesp.2018.353.3913.

6. Ministerio de Salud. Directiva Sanitaria para la Vigilancia Epidemiológica de la Enfermedad por Coronavirus (COVID-19) en el Perú MINSA; 2020 [cited 2021 March 6]. Available from: http://www.dge.gob.pe/portal/docs/tools/ teleconferencia/2020/SE452020/03.pdf

7. World Health Organization. Medical certification, ICD mortality coding, and reporting mortality associated with COVID-19 WHO; 2020 [cited 2021 March 6]. Available from: https://www.who.int/publications/i/item/WHO-2019nCoV-mortality-reporting-2020-1

8. Pan American Health Organization. Coding of COVID-19 with ICD-10; 2020 [cited 2020 Jul 29]. Available from: https://www.paho.org/arg/ dmdocuments/2019-ncov-1/documentos/COVID-19-CIE-codigos-2020-03-25spa.pdf

9. IDL-Reporteros. Los muertos que el Gobierno no cuenta [cited 2020 Dec 20]. Available from: https://www.idl-reporteros.pe/los-muertos-que-elgobierno-no-cuenta/

\section{Publisher's Note}

Springer Nature remains neutral with regard to jurisdictional claims in published maps and institutional affiliations.

\section{Submit your manuscript to a SpringerOpen ${ }^{\circ}$ journal and benefit from:}

- Convenient online submission

- Rigorous peer review

- Open access: articles freely available online

High visibility within the field

- Retaining the copyright to your article

Submit your next manuscript at $\boldsymbol{\nabla}$ springeropen.com 